\title{
An Empirical Study on Perceptions of Youth towards Peace Education in Kashmir
}

\author{
Altaf Ahmad Dar1, Prof. M.S.Lalithamma2 \\ 1 PhD scholar, School of Education Pondicherry University, India \\ 2 Professor, School of Education Pondicherry University, India
}

\begin{abstract}
This paper outlines an importance for introducing Peace Education programmes in Kashmir. Peace Education programmes addresses the forms of violence and the systems sustaining the presence of that violence. Peace Education is a process of developing knowledge, skills, attitudes, behaviours and values that enable learners to resolve conflicts through non- violent way and mutually beneficial, harmonious relationships. The author highlights the significance of Peace Education programmes in relation to different parameters like its relevance, internal conflict resolution, and problems of youth and overall development of Kashmir. Implications for practice include recommendations for policy makers to implement an initiative of peace programmes in schools as a means of reduce violence in Kashmir.
\end{abstract}

\section{Introduction}

Peace is a concept that includes many different meanings and the pathways to Peace are multidimensional. Many people view peace as the absence of all forms of direct violence. Others view it as peace of mind. Peace is also sometimes defined as a meeting of all of one's basic requirements. However, peace is more than a feeling of calm, an absence of violence, and a meeting of basic requirements. It is the presence of justice, love, equality, and unity in all aspects of life. M.K. Gandhi, for instance, believed that "if we are to teach real peace in this world and if we are to carry on a real war against war, we shall have to begin with the children".Galtung describes peace as the absence of violence. He differentiated between, positive peace and negative peace. The first implies the existence of cooperation in society and a capacity for resolving conflicts non-violently. The second, negative peace means those measures like collective security, disarmament, international court system which limits and prevents war.

\section{The Idea And History Of Peace Education}

The field of Peace education seeks to minimise direct, structural and cultural forms of violence through the transformation of educational content, structure and pedagogy. Itis teaching the information, attitudes, values, and behavioural competencies needed to resolve conflicts without violence and to build and maintain mutually beneficial, harmonious relationships. According to UNICEF "peace education refers to the process of promoting the knowledge, skills, attitudes and values needed to bring about behaviour changes that will enable children, youth and adults to prevent conflict and violence, both overt and structural; to resolve conflict peacefully; and to create conditions conducive to peace". The term peace education displays its basic idea for using education to strive towards peace. In 1945 when after World War II the United Nations was founded to promote peace in the world, the importance of education was acknowledged: "Since wars begin in the minds of men, it is in the minds of men that the defences of peace must be constructed". More than 50 years after this resolution, the UN still see the need for peace in the world. The period 2001-2010 was declared as the "International Decade for a Culture of Peace and Non-Violence for the Children of the World", with education as a central element identified to achieve what they define as a set of values, attitudes, traditions and modes of behaviour and ways of life based on: Respect for life, ending of violence and promotion and practice of nonviolence through education, dialogue and cooperation.

\section{Peace Education In India}

Many institutions in the India are working for the promotion of peace, particularly Gandhianideas of peace, the Gandhi Peace Foundation, Gandhi Smriti and DarshanSamriti, Gandhian Institute of Studies, and Jaipur Peace Foundation being prominent examples. It is unfortunate that peace education continue to be ignored by educational institutions in India. From ancient times India is rich in cooperation, peace, ahimsa and Gandhian ideas on violence have influenced the peace proponents all over the world. Although NonGovernmental Organisations (NGOs) have been contributing to different aspects of peace studies, viz., human rights, gender discrimination, environment etc, they do not impact education adequately at the school level. There is need for coordination among all such institutions in order to enhance their effectiveness. However, the social movements towards equity justice inspired by Gandhi, and his belief in education for self-reliance and 
moral development have, with a few exceptions been largely absent from peace education scholarship. UNESCO awarded the City Montessori School in Lucknow, India the 2002 UNESCO Prize for Peace Education, citing the school's efficacy in 'promoting the values of peace, religious harmony, tolerance and coexistence among children'. Most recently, the National Council of Educational Researchand Training (NCERT) in India has included peace education (referencing Gandhi's legacy as well in this regard) in its teacher education program, giving in-service teachers the opportunity to participate in a six-week long training that deals with skills, attitudes, knowledge and behaviour related to peace and nonviolence. On Feb 3, 2008 Former chief of Navy Admiral Ramadas along with peace activists called for including peace education in school syllabus. "In our school days we barely learnt anything about the heavy costs of war and impact of weapons of mass destruction. But at least the new generation should learn the lessons for lasting peace," said Admiral Ramdas. With regard to peace education the NCF (2005) recommends creating an environment that builds sensitivity to others' cultures, perspectives and rights, clearly stating that education must be oriented towards values associated with "peaceful and harmonious coexistence.". There is also a strong emphasis on reorienting education, so that it does not merely lay down the rules for ethical conduct but also nurtures the need to reason, understand and make informed choices. The NCF guidelines for integrating peace education in the curriculum have three main areas of focus: teacher training, content and peace activities for students.

\section{Need Of Peace Education In Kashmir}

Throughout history, Kashmir has gone through different devastating times. Conflict and violence have killed 43,460 of people from 1990 to 2011. The only way to save our children from this culture of violence is to imparting peace education in schools. It is the most significant way of promoting a culture of peace. Peace education needs to be accepted in all areas of the Kashmir as an essential element in creating culture of peace. To meet effectively the challenges posed by the present complexity of our time, the young of today deserves a radically different education "one that does not glorify war but educates for peace, non-violence and cooperation". They need the skills and knowledge to create and nurture peace for their individual selves as well as for the world they belong to. As Maria Montessori had articulated so appropriately, those who want a violent way of living prepare young people for that; but those, who want peace have neglected their young children and adolescents and that way are unable to organize them for peace. Looking at the Kashmir today any sensible person feels disheartened and even horrified to see the kind of violent acts being committed by man against man and nature. It is sad to realize that we live in an era of unprecedented violence in the forms of war, crimes, injustice and oppression and exploitation amidst a seemingly outward development enjoyed by a few. The saddest part of the story is that this state of disorder and confusion in the Kashmiri society is affecting the children's innocent minds. Children naturally absorb the spirit of violence in the atmosphere and will soon grow to be the next generation of perpetuators of violence. Therefore the need to nurture peace in the hearts of children has arisen as urgent issues to be addressed. It is the duty of educationists to develop peace education programmes so that the student of tomorrow in Kashmir live a conflict-free life in school, to build up mutual cooperation and successful and most of all, to live as a peaceful citizen. The main aim of peace education in Kashmir is to educate the youth towards the situations in which they live. Due to awareness about their oppressive and exploitative conditions they become capable of initiating efforts to eliminate structural violence which is the cause of physical violence. The Centre for Dialogue and Reconciliation based NGO Delhi working on peace education in Kashmir states that, 'young people were well trained to use a gun and to nurture violence. But no one had attempted to teach them to build peace and resolve conflict'.

\section{Research Objectives}

The main objectives of this study are:

1. To examine the perceptions of the youth regarding the importance of peace education in Kashmir.

2. To analyze the relevance of peace education for the peace and development of Kashmir.

\section{Methodology}

The study is based on both primary and secondary data and that are considered as pillar and foundation for the present exercise. Primary data was collected through a well-structured questionnaire that included both open ended and closed ended questions. The study had been carried out on 300 youth of Kashmir (District Anantnag) through convenient sampling method, keeping in view of their sex, locale and education. Secondary data was collected and compiled from different sources such as books, documents and other published reports which are documented by Non-Governmental Organisations (NGOs) in order to analyse the relevance of peace education for the peace and development of Kashmir. 


\section{Results And Discussion}

The main aim of peace education in Kashmir is to educate the children towards the situations in which they live. Therefore the need to implant peace in the hearts of children has arisen as urgent issues to be addressed. With these observations, some of the significant issues in relation with peace education have discussed and the findings are as follows:

Peace education and its relevance in Kashmir: Most of the youth on the basis of sex, education and locale believed that peace education is relevant in Kashmir (Table 1). Because from last 20 years kashmiries are suffering from different forms of violence. Thousands of lives have been lost since 1989 due to the intensification of the conflict. According to official figures released in Jammu and Kashmir assembly, there were 3,400 disappearance cases and the conflict has left more than 47,000 people dead as of July 2009. Conflict has impacted all sections of the society in Kashmir. Hence peace education in Kashmir is relevant that will focus on curriculum that aims at teaching justice, non-violence, human rights disarmament and environmental problems and issues relevant to peace. As per the study conducted by AnupamaSrinivasan, 'A Survey of Civil Society Peace Education Programmes in South Asia' in 2008 states that on-going, protracted conflicts in Jammu and Kashmir have necessitated the peace programmes. By introducing young people to concepts of peace and diversity, they hope to inhibit the recruitment practices of terrorist groups based in the region. For this reason, projects working in the area also strive to improve the overall quality of education the children receive, and thereby their job prospects. This in turn could also lower the possibility of young people being conscripted into violence.

Peace Education and internal conflict resolution: Peace education will introduce new peaceful concepts about the conflict resolution and the youth of Kashmir will be ready to adopt peaceful means for the resolution of internal issues of Kashmir. Majority of the youth have supported that peace education will create means for the resolution of internal issues of Kashmir. MihirDesaiinhis article, 'Peace Education' writes that over the past five decades, gruelling poverty, misgovernance, political manipulation of religion, gender disparities and caste and ethnic conflicts have warped and wounded the daily life of South Asia's nearly one and a half billion people. Military build- ups with nuclear implications pose huge additional burdens and hazards. Economic advancement has been blocked and basic rights like health care, universal education and employment remain out of bounds for the vast majority of South Asia's inhabitants, perhaps nowhere more so than in the Jammu and Kashmir Valley. Violence has affected the development scenario in the state of J\&K, thereby not only discouraging private investment, but also creating obstacles in effective implementation of the developmental policies initiated by public authorities.It is true that peace education will create new avenues in tourism, economic development, peace culture and means for the resolution of internal issues of Kashmir.

Peace Education and Problems of youth: Most of the youth clearly states that peace education will solve the basic problems whether it is social, political, and economic. Prof. J.A.K. Tareen, former Vice-Chancellor, Pondicherry University once stated at a national seminar on 'Conflict in Kashmir: Challenges Ahead' organised by the Department of Defence and Strategic Studies of the University of Madras that the unemployed youth looked at Kashmir as a failing State. It was not the truth but the Kashmiri youth perceived it as truth. The fragmented nature of the polity meant that there was no homogenous thought, posing a major political challenge. The fundamental problems to be tackled in Jammu and Kashmir are corruption and poor governance .A million youth in Kashmir were looking towards India for opportunities. When India was conquering peaks in Information Technology, the Kashmiris had no institution to teach computer science. "The issue of Kashmir is a genuine issue. Many leaders come here and go but do not listen to the problems of the Kashmiri youth. The Kashmiri youth are facing unemployment," a local youth told. According to a survey conducted by the Chatham House (UK) some time back, $96 \%$ of respondents from the Kashmir valley identified unemployment as one of the main problems facing the state along with conflict and mounting corruption. A report by US based NGO notices that, 'jobs are few, and those that are available are often filled through elite connections and nepotism measures'. Peace education will create more employment avenues for the youth.

Most of the respondents believed that peace education will solve psychological problems of youth which has been created by 20 years' war like tension, heart problems, fear etc. Stone pelting is one of the biggest problems among the youth which Kashmir is facing. The youth wanted to progress, they were not allowed to do so. One respondent said that "We want an opportunity to move ahead. You also see that we are not allowed to move ahead. When we protest, there is firing which is not the case in other states". No doubt they have some grievances about state administration but they can convince them through peaceful means. Hence most of the respondents believed that peace education will create new peaceful means instead of stone pelting for redresses of their grievances.

Peace education and Educational system in Kashmir: Education is defined by transmitting knowledge, skills and values and thus is expected to have a formative effect on the targeted individuals. Peace education programmes and workshops should be conducted to transmit peace skills and values to students. These programmes will promote core skills such as harmony, honesty, compassion, and handling aggression among 
students and other such skills that they come across on a daily basis. Most of the youth believed that peace education content should be incorporated in textbooks. An analysis of the textbooks for Classes IV, V, and VI of government schools in Kashmir shows that not a single character can be identified as coming from a Muslim background. Yet a large proportion of the students in these schools are from the erstwhile Muslim communities. Exclusion is a form of violence. It breeds a sense of inferiority. Every textbook must be thoroughly and critically reviewed for its contents, treatment, and overall vision. On the negative side, textbooks need to be kept clear of anti-peace ideas, assumptions, and attitudes. From a positive angle, it needs to be ensured that they appropriate 'peace opportunities' optimally. Attention needs to be paid to the language used in textbooks so as to ensure that their sensibility is conducive to nurturing courteous, aesthetically-sensitive, and socially-aware human beings. Role of Secular personalities like Lalleshwari, a saint revered by both Hindus and Muslims, who defied caste structures, left her home and husband, and became a leader of the people should be taught in schools.

\section{Conclusion}

Peace education is very important to reduce violence and promote the culture of tolerance, harmony among different groups in Kashmir. There is a need to start peace education programmes in schools, colleges and universities. Educating young people about peace would mean those aspects of daily life which are deeply connected to ones identity become part of the daily school level curriculum. Education is a key to empowerment, yet if the content of Peace is added in it; it becomes the way to sustainable peace, understanding, co-existence and development in the state as well as beyond. Thus, introduction of Peace Education at all the levels especially at pre-school and school level is the need to change the traditional stereoscopes of budding minds and build their minds positive towards one another, and enable them to be responsible citizens over time, hence prevent future conflicts, overcome the communal riots within national boundaries or combat so called terrorism beyond the borders. Hence peace Education will prove beneficial for resolution of Kashmir problem and overall development of Kashmir. It will also solve the major problems of the young people. Most of the youth became victims of ignorance, violence, anger, hatred, despair, terrorism and now peace education is the only way for them to come out from this gloomy situation. So there is urgent need to instil peace in education if we want to prevent future generations from the scourge of war. The following are the suggestions for policy makers.

1. Peace clubs and peace libraries should be set up in schools with supplementary reading materials that promote peace values and skills.

2. There should be provisions in schools to enable students to celebrate: (a) the cultural and religious diversity of India, (b) Human Rights Day (c) Day for the Differently-able (d) Girl Child Day (e) Women's day (f) Environment Day.

3. Availability of short-term exchanges between students from various streams to help students overcome prejudices, regional, caste, and class barriers.

4. Organisation of workshops in education for peace for teachers, principals and parents.

5. Topics related to peace education should be included in all subjects

6. NGO's should be encouraged to run peace education projects.

7. There should be coordination between Govt., NGO's and schools for running of peace education programmes.

Table 1

Showing the percentage of respondents on relevance of peace education in Kashmir

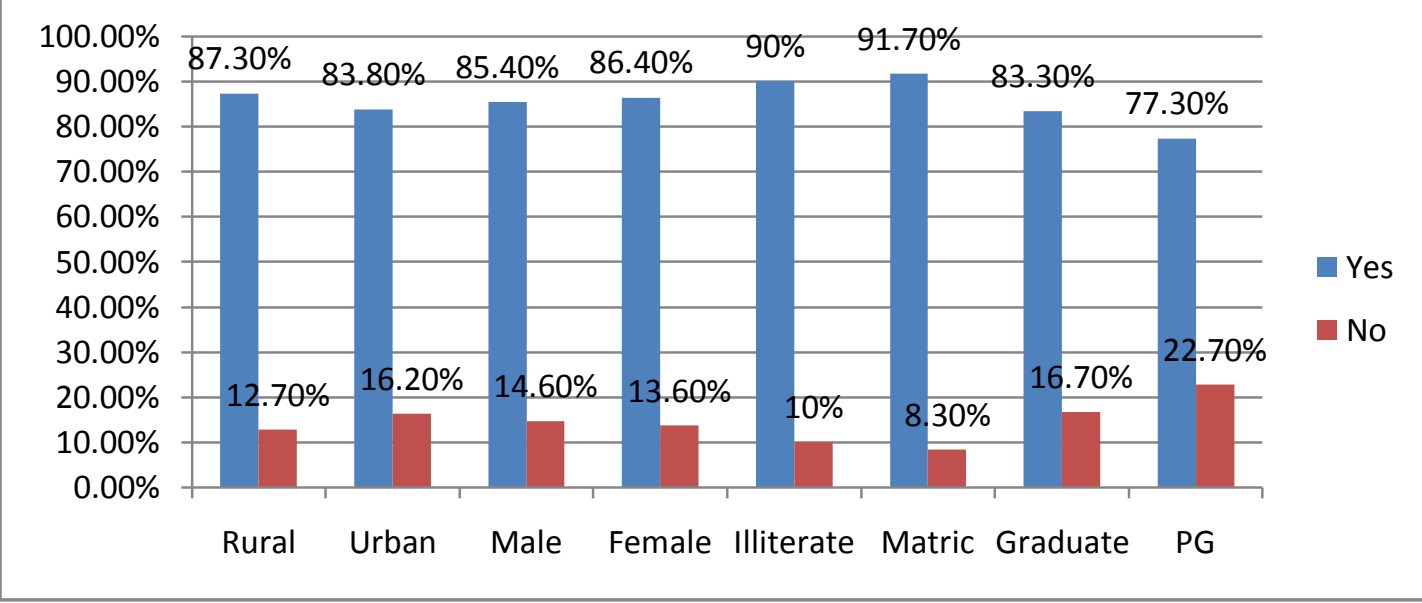




\section{References}

[1]. Rajagopalan, Priyadarshini (2009): "From Agenda to Action: Interpreting and Implementing the NCF Peace Education Guidelines",Educational Policy Research Series, Volume I, Number 3.

[2]. Najjuma, Rovincer (2011): Peace Education in the Context of Post-Conflict Formal Schooling: The Effectiveness of the Revitalising Education Participation and Learning in Conflict Affected Areas-Peace Education Programme in Northern Uganda, Unpublished Doctoral dissertation, School of Education University Of Birmingham, http://etheses.bham.ac.uk/3083/1/Najiuma11PhD.pdf, accessed on February 3, 2013

[3]. Fountain, S (1999): Peace Education in UNICEF: Programme Publications 3 UN Plaza New York, NY 10017 USA, www.unicef.org, accessed on November 23, 2012

[4]. WWW.UNESCO.COM

[5]. UNESCO (1999): The Hague Appeal for Peace, Hague: UNESCO, www.unesco.com , accessed on December 2, 2012.

[6]. Bajaj, Monisha (2010): "Conjectures on peace education and Gandhian studies: method, institutional development and globalization", Journal of Peace Education, Vol.7, No 1, pp.47-63.

[7]. Times of India (2008): "Peace Education in School books", Feb. 3, Chennai.

[8]. The National Curriculum Framework (NCF 2005) is one of four National Curriculum Frameworks published in 1975, 1988, 2000 and 2005 by the National Council of Educational Research and Training NCERT in India. The document provides the framework for making syllabi, textbooks and teaching practices within the school education programmes in India.

[9]. NCF (2005): National Curriculum Framework, NCERT: New Delhi.

[10]. Times of India (20011): "State data refutes claim of 1 lakh killed in Kashmir conflict", June 20, 2011.

[11]. Castro, Loreta Navarro and Jasmin, Nario-Galace(2008): 'Peace Education: A Pathway to a Culture of Peace' , Centre for Peace Education Miriam College: Quezon City, Philippines .

[12]. Dar, Altaf Ahmad (2013): "Imparting Peace Education children affects most", March 9, Greater Kashmir: Srinagar.

[13]. Wani, Showket Rashid (2010): "Peace education in schools" www.jandknow.com 25 Sep. 2010.

[14]. Srinivasan ,Anupama(2008): “A Survey of Civil Society Peace Education Programmes in South Asia”, Educational Policy Research Series, Volume I ,Number, 2 August.

[15]. This study was conducted by Chennai based NGO The Pranjya Trust which is working for peace, justice and security

[16]. Desai, Mihir (2004): 'Peace Education' AAKASH, AshaStanfords Quarterly Newsletter, Volume1 issue 3.

[17]. Mahapatra ,DebidattaAurobinda and Shekhawat ,Seema(2008): The Peace Process and Prospects for Economic Reconstruction in Kashmir', Peace and Conflict Review · Volume 3 Issue 1 .

[18]. I have personally participated in this seminar in March 21, 2011, for more information The Hindu(Chennai edition) March $22,2011$.

[19]. It was said by one of the respondent during interview in Govt Degree College Anantnag Kashmir on Dec. 20,2011

[20]. Youth Entrepreneurship in Kashmir: Challenges and Opportunities, Project,www.mercycorps.org/sites/.../youth entrepreneurship in kashmir.pd, accessed on March 10,2012

[21]. Saadut, Economic opportunities denied: Kashmir, http://www.saadut.com/2011/11/economic-opportunities-denied-kashmir.html , accessed on March 2, 2012.

[22]. This view was expressed by one of the respondent during interview in Govt Degree College Anantnag Kashmir on Dec. 20,2011

[23]. As per the results of the Questionnaire 